\title{
Unconventional Reservoirs
}

\author{
Contributors: , Muhammad Ali ${ }^{1}$, Adnan Aftab $^{2}$ \\ 1, Curtin University Edith Cowan University; muhammad.ali7@postgrad.curtin.edu.au \\ 2, Mehran University of Engineering and Technology Edith Cowan University; \\ Adnanaftab@muetkhp.edu.pk
}

Version received: 13 July 2020

check for updates

The world's energy demand is steadily increasing where it has now become not easy for conventional hydrocarbon reservoirs to meet levels of demand. Therefore, oil and gas companies are seeking novel ways to exploit and unlock the potential of unconventional resources. Drilling of high-pressure high-temperature (HPHT) wells and shale reservoirs has become more widespread in the global petroleum and natural gas industry. There is a current need to extend robust techniques beyond costly drilling and completion jobs, with the potential for exponential expansion. This paper explains a better understanding of the selection of drilling fluids and additives for unconventional hydrocarbon reservoirs.

\section{Definition}

The world's energy demand is steadily increasing where it has now become difficult for conventional hydrocarbon reservoirs to meet levels of demand. Therefore, oil and gas companies are seeking novel ways to exploit and unlock the potential of unconventional resources. These resources include tight gas reservoirs, tight sandstone oil, oil and gas shales reservoirs, and high-pressure high-temperature (HPHT) wells. Drilling of HPHT wells and shale reservoirs has become more widespread in the global petroleum and natural gas industry. There is a current need to extend robust techniques beyond costly drilling and completion jobs, with the potential for exponential expansion. Drilling fluids and their additives are being customized in order to cater for HPHT well drilling issues. Certain conventional additives, e.g., filtrate loss additives, viscosifier additives, shale inhibitor, and shale stabilizer additives are not suitable in the HPHT environment, where they are consequently inappropriate for shale drilling. A better understanding of the selection of drilling fluids and additives for hydrocarbon water-sensitive reservoirs within HPHT environments can be achieved by identifying the challenges in conventional drilling fluids technology and their replacement with eco-friendly, cheaper, and multi-functional valuable products. In this regard, several laboratory-scale literatures have reported that nanomaterial has improved the properties of drilling fluids in the HPHT environment.

\section{Introduction}

Drilling fluids are essential consumables for drilling and exploration activities. Every drilling activity requires an appropriate drilling fluids program, where they are used extensively across the globe. Different types of drilling fluids are available within the market with differing performances designed to fit selective purposes, in addition to varied costs of fluid and environmental impacts [1][2]. The consumption of drilling fluids and additives depends directly on drilling fluid activities that are carried out globally. The increasing demand for energy has encouraged oil and gas companies to drill unconventional reservoirs in order to fulfill energy supply. Energy demand can be compensated through unconventional resources include heavy oil [3][4], gas hydrates [5], coal bed methane[6][7][8][9][10][11], tight gas [12][13][14][15][16], gas and oil shale [16][17][18], and high pressure high temperature (HPHT) wells [19][20][21]. New explorations in HPHT environments has led to a rise in drilling activities globally. The HPHT environment (i.e., $422-589 \mathrm{~K}$ and pressure of $138 \mathrm{MPa}$ to $276 \mathrm{MPa}$ ) requires suitable techniques and selection of particular technologies in order to conduct drilling into extreme environments [22]. Likewise, formulations of drilling fluids play an important role in drilling within HPHT environments. Therefore, oil-based drilling fluids (OBDF) have been repeatedly used in HPHT drilling fluid systems, where they have been shown to be effective in shale drilling in HPHT downhole environments [23]. However, OBDF is toxic for marine species [24] and involves a high cost $[25]$ because it is mostly made up of diesel oil[26]. Therefore, investigators have been consistently working to improve the characteristics of the water-based drilling fluid system (WBDF) for unconventional reservoirs and drilling operations, where WBDF is inexpensive [27] and 
environmentally friendly [28]. Eighty percent of oil and gas wellbore drilling operation uses WBDF[29]; however, WBDF possesses several problems related to drag and torque, pipe sticking, formation damage, lost circulation, and wellbore instability within HPHT downhole environments. However, researchers are currently working on improvements to WBDF systems using polymers to enhance rheology, reduce filtrate loss and shale inhibition, and to increase salt resistance [30][31][32].

Recently, researchers have widely studied polymeric material in conjunction with bentonite to prepare drilling fluids for harsh conditions, in particular HPHT [33][34]. Molecules of polymer have long carbon chains and yield viscosity in the solution form [32][35]; thus, influencing rheology filtrate loss and lubricity of drilling fluid systems 5 [1][36]. Some natural polymers, in particular guar gum, starch, and cellulose, have been successfully used alongside bentonite to achieve adequate drilling fluid properties [37]. Naturally available polymers have been widely used due to their low cost ${ }^{[38]}$, and environmentally friendly nature [39]. Nonetheless, natural polymers have low-temperature stability [40][41][42]. High temperatures render the superior and thixotropic properties of polymers inactive, adversely affecting rheological characteristics and resulting in a loss of drilling fluid [43], inappropriate cutting, lifting barite sag problems ${ }^{[44][45]}$, and increasing the cost of drilling. Recently, Jain et al. ${ }^{[46]}$ found that grafted polymer showed better rheological properties and filtration performance compared to carboxymethyl cellulose (CMC) when considered as a drilling fluid additive for shale drilling. Ternary copolymer reduced the fluid loss in the presence of high salt content of drilling fluid additives and resulted in better salt tolerance. Moreover, the copolymer produced better thermal stability within the drilling fluid system [29]. Nonetheless, some cellulose polymers have been shown to degrade at 483 to $533 \mathrm{~K}[\underline{47]}$, where polyacrylamide was substantially lost at around $378 \mathrm{~K}$ in the presence of oxygen. However, another study has reported this degradation between 388 to $723 \mathrm{~K}[48]$. Drilling engineers currently require thermally stable, multifunctional, environmental, and inexpensive durable drilling fluid additives for the drilling of unconventional HPHT reservoirs [49].

Nanosize additives with enhanced characteristics are actively being investigated in regards to drilling of HPHT wells [33][50]. Several nanomaterial have been investigated such as nano silica[51], graphene oxide [52], graphene nanoplatelets [43][53], multi-walled carbon nanotube [51][54][55], single walled carbon nanotube [54][56], nano ZnO [57][58], $\mathrm{TiO}_{2}{ }^{[59]}, \mathrm{CuO}{ }^{[60]}$, and $\mathrm{Fe}_{2} \mathrm{O}_{3}$, nano-cellulose, nano-silica polymer grafted polymer [61], ZnO polymer nanocomposite [43], $\mathrm{TiO}_{2} /$ polymer nanocomposite ${ }^{[62]}, \mathrm{TiO}_{2}$ /clay nanocomposite ${ }^{[63]}$, and several others [64].

Nanomaterials are widely used for different purposes, including enhanced oil recovery[65][66][67][68], wettability alteration [69][70][71][72], IFT reduction [73][74][75], surface adsorption [76], and $\mathrm{CO}_{2}$ storage applications [77][78][79][80][81]. They have the potential to augment rheological properties and shale inhibition of unconventional HPHT wells, but this has not been reported in a review work to date. This paper is devised to present a review on unconventional resources, HPHT wells, and drilling fluids additives used to drill HPHT and the superior role of nanomaterial additives in the drilling of HPHT wells.

\section{Data, Model, Influences and Applications}

\subsection{Designing Drilling Fluid for HPHT Environment}

High-pressure and high-temperature well drilling process is challenging and required robust drilling fluid program. Conventional drilling fluids additives in particular cellulosic polymer, and high concentration of $\mathrm{KCl}$, may rise instable rheological properties. Bern et al. 2006 stated that there are many interdependencies within the rheological and hydraulic area of the drilling bit. However, they note the important criteria in selecting base drilling fluid for HPHT operations as being: (1) environmental impacts, (2) the stability at high pressure and temperature, and (3) minimum rheology to minimize ECD and reduce the frictional pressure loss [4].

Followings are several points-to-ponder when selecting a drilling fluid system for the HPHT environment, which include:

1) Narrow drilling operating window vs. high density of HPHT drilling fluid. The importance of balancing the need for thin, low incremental pressure fluid without creating the problem of poor solids support (settling of conventional weighting materials). Moreover, high-density drilling fluids may plug nano-pores in unconventional reservoirs in 
particular shale.

2) Thermal stability of fluid products and systems. Destabilization of products and aggressive and rapid reactions towards any contaminants in the system will occur when products reach their operating condition limits.

3) The technical performance of the fluid for the HPHT environment should be placed as the main priority, not cost, as the margin for error in the HPHT environment is very small, causing the whole operation to fail with the under performance of drilling fluid.

4) The fluid and additives should not only be stable at high temperatures but must also withstand the maximum expected time under the most extreme conditions anticipated.

5) For HPHT operations, rigorous planning thorough laboratory work, detailed drilling, and well and drilling fluid programs becomes more critical, where it is important to prepare backup plans.

6) Every HPHT well is unique; thus, a specific drilling fluid design may only work for a particular well.

More importantly, the drilling fluid weight window becomes more critical when drilling with a managed pressure drilling plan. The hydrostatic pressure of the drilling fluid is controlled with the density of the drilling fluid. Thus, hydrostatic pressure could be lower compared to pore pressure according to the availability of equivalent circulation density.

\section{References}

1. Abbas, A.K.; Hamed, H.M.; Al-Bazzaz, W.; Abbas, H. Predicting the amount of lost circulation while drilling using artificial neural networks: An example of Southern Iraq oil fields. In Proceedings of the SPE Gas \& Oil Technology Showcase and Conference, Dubai, UAE, 21-23 October 2019; Society of Petroleum Engineers: Houston, TX, USA, 2019.

2. Squintani, E.; Uslenghi, A.; Ferrari, S.; Affede, L. Deepwater HPHT drilling through ultra narrow PPFG window: A case study by ENI where the combination of continuous circulation technology together with MPD drilling has been successfully applied to extreme drilling environment condition in HPHT ultra deepwater well. In Proceedings of the Abu Dhabi International Petroleum Exhibition \& Conference, Abu Dhabi, UAE, 12-15 November 2018; Society of Petroleum Engineers: Houston, TX, USA, 2018.

3. Gounder, R.M. Processing of Heavy Crude Oils-Challenges and Opportunities; IntechOpen: London, UK, 2019.

4. Gao, E.; Booth, M.; MacBeath, N. Continued improvements on high-pressure/high-temperature drilling performance on wells with extremely narrow drilling windows-experiences from mud formulation to operational practices, shearwater project. In Proceedings of the ladc/Spe Drilling Conference, New Orleans, LA, USA, 23-25 February 2000; Society of Petroleum Engineers: Houston, TX, USA, 2000.

5. Shukla, K.; Kumar, P.; Yadav, U. Gas hydrate reservoir identification, delineation, and characterization in the Krishna-Godavari basin using subsurface geologic and geophysical data from the national gas hydrate program 02 expedition, offshore India. Mar. Pet. Geol. 2019, 108, 185-205.

6. Mastalerz, M.; Drobniak, A. Coalbed methane: Reserves, production, and future outlook. In Future Energy; Trevor, M., Ed.; Elsevier: Amsterdam, The Netherlands, 2020; pp. 97-109.

7. Akhondzadeh, H.; Keshavarz, A.; Al-Yaseri, A.Z.; Ali, M.; Awan, F.U.R.; Wang, X.; Yang, Y.; Iglauer, S.; Lebedev, M. Pore-scale analysis of coal cleat network evolution through liquid nitrogen treatment: A Micro-Computed Tomography investigation. Int. J. Coal Geol. 2020, 219, 103370.

8. Awan, F.U.R.; Keshavarz, A.; Akhondzadeh, H.; Al-Anssari, S.F.; Al-Yaseri, A.Z.; Nosrati, A.; Ali, M.; Iglauer, S. Stable Dispersion of Coal Fines During Hydraulic Fracturing Flowback in Coal Seam Gas Reservoirs-An Experimental Study. Energy Fuels 2020, 34, 5566-5577.

9. Mushtaq, F.; Qadeer, A.; Mir, F.; Aftab, A. Coal fired power generation potential of balochistan. Pet. Coal $2012,54$.

10. Keshavarz, A.; Badalyan, A.; Carageorgos, T.; Johnson, R.; Bedrikovetsky, P. Stimulation of unconventional naturally fractured reservoirs by graded proppant injection: Experimental study and mathematical model. In Proceedings of the SPE/EAGE European Unconventional Resources Conference and Exhibition, Vienna, Austria, 25-27 February 2014; European Association of Geoscientists \& Engineers: Db Houten, The Netherlands, 2014; pp. 1-12.

11. Akhondzadeh, H.; Keshavarz, A.; Sayyafzadeh, M.; Kalantariasl, A. Investigating the relative impact of key reservoir parameters on performance of coalbed methane reservoirs by an efficient statistical approach. J. Nat. Gas Sci. Eng. 2018, 53, 416-428.

12. Slavens, M.J.; Tyler, K.F. Development of a sour HPHT environment corrosion-fatigue SN design curve. In Proceedings of the Offshore Technology Conference, Houston, TX, USA, 4-7 May 2019.

13. Mahesar, A.A.; Shar, A.M.; Ali, M.; Tunio, A.H.; Uqailli, M.A.; Mohanty, U.S.; Akhondzadeh, H.; Iglauer, S.; Keshavarz, A. Morphological and petro physical estimation of eocene tight carbonate formation cracking by cryogenic liquid nitrogen; a case study of Lower Indus basin, Pakistan. J. Pet. Sci. Eng. 2020, 107318. 
14. Memon, K.R.; Mahesar, A.A.; Ali, M.; Tunio, A.H.; Mohanty, U.S.; Akhondzadeh, H.; Awan, F.U.R.; Iglauer, S.; Keshavarz, A. Influence of Cryogenic Liquid Nitrogen on petro-physical characteristics of Mancos Shale: An Experimental Investigation. Energy Fuels 2020, 34, 2160-2168.

15. Muther, T.; Nizamani, A.A.; Ismail, A.R. Analysis on the effect of different fracture geometries on the productivity of tight gas reservoirs. Malays. J. Fundam. Appl. Sci. 2020, 16, 201-211.

16. Abro, Z.; Mengal, A.N.; Tunio, A.H.; Nizamani, A.A. Reserve Estimation Technique for Low Permeability Shale Gas Formations of Lower Indus Basin, Using Simulation Approach. J. Appl. Emerg. Sci. 2018, 8, 24-31.

17. Boak, J.; Kleinberg, R. Shale gas, tight oil, shale oil and hydraulic fracturing. In Future Energy; Trevor, M., Ed.; Elsevier: Amsterdam, The Netherlands, 2020; pp. 67-95.

18. Qadeer, A.; Aftab, A.; Nazir, I. Optimization of energy consumption during natural gas dehydration. J. Appl. Emerg. Sci. 2012, 3, 711.

19. Chaudhary, S.; Singh, S.; Singh, V.K. A novel approach for formulating CO foam based fracturing fluid by synthesized grafting copolymerization to enhance its stability for HPHT shale reservoirs. In Proceedings of the SPE Middle East Oil and Gas Show and Conference, Manama, Bahrain, 12-14 March 2019; Society of Petroleum Engineers: Houston, TX, USA, 2019.

20. Smith, S.R.; Rafati, R.; Haddad, A.S.; Cooper, A.; Hamidi, H. Application of aluminium oxide nanoparticles to enhance rheological and filtration properties of water based muds at HPHT conditions. Colloids Surf. A Physicochem. Eng. Asp. 2018, 537, 361-371.

21. Seetharaman, G.R.; Sangwai, J.S. Effect of Nanoparticles on the Performance of Drilling Fluids. In Nanotechnology for Energy and Environmental Engineering; Sangwai, J.S., Ledwani, L., Eds.; Springer: Berlin/Heidelberg, Germany, 2020; pp. $279-297$.

22. Aftab, A.; Ali, M.; Sahito, M.F.; Mohanty, U.S.; Jha, N.K.; Akhondzadeh, H.; Azhar, M.R.; Ismail, A.R.; Keshavarz, A.; Iglauer, S. Environmental-friendly and high-performance of multifunctional Tween 80/ZnO nanoparticles added water-based drilling fluid: an experimental approach. Sustain. Chem. Eng. 2020, accepted.

23. Huaike, L.; Tie, G.; Lei, G.; Jiansheng, L. High Performance Water-based Drilling Fluids-A High Efficiency Muds Achieving Superior Shale Stability While Drilling Deepwater Well with HPHT in South China Sea. Science 2019, 7, 98-103.

24. Okoro, E.E.; Ochonma, C.; Omeje, M.; Sanni, S.E.; Emetere, M.E.; Orodu, K.B.; Igwilo, K.C. Radiological and toxicity risk exposures of oil based mud: health implication on drilling crew in Niger Delta. Environ. Sci. Pollut. Res. 2020, 27, 5387-5397.

25. Sheer, S.; Alotaibi, A.; Gadhiya, K.; Al-Khaldy, M.; Abhijit, D.; Al-Failkawi, K.; Al-Saadi, D.; Al-Saeedi, A.; Hamed, A.; Al-Azmi, F. The dynamics of drilling with oil-based mud, 60: 40 oil-water ratio-case history in South East Kuwait fields. In Proceedings of the SPE Gas \& Oil Technology Showcase and Conference, Dubai, UAE, 21-23 October 2019; Society of Petroleum Engineers: Houston, TX, USA, 2019.

26. Hursan, G.; Ma, S.M.; Valori, A.; Sauerer, B. Study of OBM invasion on NMR logging-mechanisms and applications. In Proceedings of the SPE Kingdom of Saudi Arabia Annual Technical Symposium and Exhibition, Dammam, Saudi Arabia, 23-26 April 2018; Society of Petroleum Engineers: Houston, TX, USA, 2018.

27. Zamani, A.; Bataee, M.; Hamdi, Z.; Khazforoush, F. Application of smart nano-WBM material for filtrate loss recovery in wellbores with tight spots problem: an empirical study. J. Pet. Explor. Prod. Technol. 2019, 9, 669-674.

28. Al-Saba, M.; Amadi, K.; Al-Hadramy, K.; Al Dushaishi, M.; Al-Hameedi, A.; Alkinani, H. Experimental investigation of bio-degradable environmental friendly drilling fluid additives generated from waste. In Proceedings of the SPE International Conference and Exhibition on Health, Safety, Security, Environment, and Social Responsibility, Abu Dhabi, UAE, 16-18 April 2018; Society of Petroleum Engineers: Houston, TX, USA, 2018.

29. Hamad, B.A.; He, M.; Xu, M.; Liu, W.; Mpelwa, M.; Tang, S.; Jin, L.; Song, J. A Novel Amphoteric Polymer as a Rheology Enhancer and Fluid-Loss Control Agent for Water-Based Drilling Muds at Elevated Temperatures. ACS Omega 2020, 5, 8483-8495.

30. Ahmad, H.M.; Kamal, M.S.; Murtaza, M.; Al-Harthi, M.A. Improving the drilling fluid properties using nanoparticles and water-soluble polymers. In Proceedings of the SPE Kingdom of Saudi Arabia Annual Technical Symposium and Exhibition, Dammam, Saudi Arabia, 24-27 April 2017; Society of Petroleum Engineers: Houston, TX, USA, 2017.

31. Liu, X.; Yuan, Z.; Wang, A.; Wang, C.; Qu, J.; Chen, B.; Wei, B.; Kapu, N.S.; Wen, Y. Cellulose nanofibril-polymer hybrids for protecting drilling fluid at high salinity and high temperature. Carbohydr. Polym. 2020, 229, 115465.

32. Ahmad, H.M.; Kamal, M.S.; Al-Harthi, M.A. High molecular weight copolymers as rheology modifier and fluid loss additive for waterbased drilling fluids. J. Mol. Liq. 2018, 252, 133-143.

33. Gautam, S.; Guria, C. Optimal Synthesis, Characterization, and Performance Evaluation of High-Pressure High-Temperature Polymer-Based Drilling Fluid: The Effect of Viscoelasticity on Cutting Transport, Filtration Loss, and Lubricity. SPE J. 2020, 25, 1333-1350.

34. Salam, M.; Al-Zubaidi, N.S.; Al-Wasiti, A.A. Enhancement in Lubricating, Rheological, and Filtration Properties of Unweighted WaterBased Mud Using XC Polymer NPs. J. Eng. 2019, 25, 96-115.

35. Jin, Y.-J.; Choi, Y.-G.; Kwak, G. Molecular rotors with long alkyl chains as fluorescent viscosity sensors for hydrocarbon and silicone oil fluids. J. Mol. Liq. 2019, 276, 1-6.

36. Amanullah, M.; Yu, L. Environment friendly fluid loss additives to protect the marine environment from the detrimental effect of mud additives. J. Pet. Sci. Eng. 2005, 48, 199-208.

37. Kerunwa, A.; Gbaranbiri, B.A. Evaluation of local viscosifiers as an alternative to conventional Pac-R. Adv. Pet. Explor. Dev. 2018, 
$15,1-8$.

38. Mohanty, A.; Misra, M.a.; Hinrichsen, G. Biofibres, biodegradable polymers and biocomposites: An overview. Macromol. Mater. Eng. 2000, 276, 1-24.

39. Liu, X.; Gao, Y.; Hou, W.; Ma, Y.; Zhang, Y. Non-toxic high temperature polymer drilling fluid significantly improving marine environmental acceptabiiity and reducing cost for offshore drilling. In Proceedings of the International Petroleum Technology Conference, Beijing, China, 26 March 2019; Springer: Berlin/Heidelberg, Germany, 2019.

40. Song, A.; Huang, Y.; Zhong, X.; Cao, H.; Liu, B.; Lin, Y.; Wang, M.; Li, X. Gel polymer electrolyte with high performances based on pure natural polymer matrix of potato starch composite lignocellulose. Electrochim. Acta 2017, 245, 981-992.

41. Dayo, A.Q.; Zegaoui, A.; Nizamani, A.A.; Kiran, S.; Wang, J.; Derradji, M.; Cai, W.-a.; Liu, W.-b. The influence of different chemical treatments on the hemp fiber/polybenzoxazine based green composites: Mechanical, thermal and water absorption properties. Mater. Chem. Phys. 2018, 217, 270-277.

42. Dayo, A.Q.; Xu, Y.-L.; Zegaoui, A.; Nizamani, A.A.; Wang, J.; Zhang, L.; Liu, W.-B.; Shah, A.H. Reinforcement of waste hemp fibres in aromatic diamine-based benzoxazine thermosets for the enhancement of mechanical and thermomechanical properties. Plast. Rubber Compos. 2017, 46, 442-449.

43. Aftab, A.; Ismail, A.; Ibupoto, Z. Enhancing the rheological properties and shale inhibition behavior of water-based mud using nanosilica, multi-walled carbon nanotube, and graphene nanoplatelet. Egypt. J. Pet. 2016, 26, 291-299.

44. Basfar, S.; Mohamed, A.; Elkatatny, S.; Al-Majed, A. A Combined Barite-Ilmenite Weighting Material to Prevent Barite Sag in WaterBased Drilling Fluid. Materials 2019, 12, 1945.

45. Amighi, M.; Shahbazi, K. Effective ways to avoid barite sag and technologies to predict sag in hpht and deviated wells. In Proceedings of the SPE Deep Gas Conference and Exhibition, Manama, Bahrain, 24-26 January 2010; Society of Petroleum Engineers: Houston, TX, USA, 2010.

46. Jain, R.; Paswan, B.K.; Mahto, T.K.; Mahto, V. Study the effect of synthesized graft copolymer on the inhibitive water based drilling fluid system. Egypt. J. Pet. 2017, 26, 875-883.

47. Fan, M.; Fu, F. 1-Introduction: A perspective-natural fibre composites in construction. In Advanced High Strength Natural Fibre Composites in Construction; Fan, M., Fu, F., Eds.; Woodhead Publishing: Cambridge, UK, 2017; pp. 1-20.

48. Leung, W.; Axelson, D.; Van Dyke, J. Thermal degradation of polyacrylamide and poly (acrylamide-co-acrylate). J. Polym. Sci. Part A Polym. Chem. 1987, 25, 1825-1846.

49. Aftab, A. Optimizing The Behavior of Water-Based Drilling Fluids Using Nano-Micron Composite Material. Available online: https://www.academic-conferences.org/blog-post/june-2016-newsletter/ (accessed on 12 June 2016).

50. Noah, A.; El Semary, M.; Youssef, A.; El-Safty, M. Enhancement of yield point at high pressure high temperature wells by using polymer nanocomposites based on ZnO \& CaCO3 nanoparticles. Egypt. J. Pet. 2017, 26, 33-40.

51. Ismail, A.R.; Sulaiman, W.; Jaafar, M.; Aftab, A.; Razi, A.; Ibupoto, Z. The application of MWCNT to enhance the rheological behavior of drilling fluids at high temperature. Malays. J. Fundam. Appl. Sci. 2016, 12, 95-98.

52. Kosynkin, D.V.; Ceriotti, G.; Wilson, K.C.; Lomeda, J.R.; Scorsone, J.T.; Patel, A.D.; Friedheim, J.E.; Tour, J.M. Graphene Oxide as a High-Performance Fluid-Loss-Control Additive in Water-Based Drilling Fluids. ACS Appl. Mater. Interfaces 2011, 4, $222-227$.

53. Aramendiz, J.; Imqam, A.; Fakher, S. Design and evaluation of a water-based drilling fluid formulation using sioz and graphene oxide nanoparticles for unconventional shales. In Proceedings of the International Petroleum Technology Conference (IPTC), Beijing, China, 13-15 January 2019; Missouri University of Science and Technology: Rolla, MO, USA, 2019.

54. Chai, Y.H.; Yusup, S.; Chok, V.S.; Arpin, M.T.; Irawan, S. Investigation of thermal conductivity of multi walled carbon nanotube dispersed in hydrogenated oil based drilling fluids. Appl. Therm. Eng. 2016, 107, 1019-1025.

55. Abduo, M.I.; Dahab, A.S.; Abuseda, H.; AbdulAziz, A.M.; Elhossieny, M.S. Comparative study of using Water-Based mud containing Multiwall Carbon Nanotubes versus Oil-Based mud in HPHT fields. Egypt. J. Pet. 2015.

56. Anoop, K.; Sadr, R.; Yrac, R.; Amani, M. Rheology of a colloidal suspension of carbon nanotube particles in a water-based drilling fluid. Powder Technol. 2019, 342, 585-593.

57. Aftab, A.; Ismail, A.; Khokhar, S.; Ibupoto, Z. Novel zinc oxide nanoparticles deposited acrylamide composite used for enhancing the performance of water-based drilling fluids at elevated temperature conditions. J. Pet. Sci. Eng. 2016, 146, $1142-1157$.

58. Ghayedi, A.; Khosravi, A. Laboratory investigation of the effect of GO-ZnO nanocomposite on drilling fluid properties and its potential on H2S removal in oil reservoirs. J. Pet. Sci. Eng. 2020, 184, 106684.

59. Kumar, R.S.; Sharma, T. Stable SiO2-TiO2 composite-based nanofluid of improved rheological behaviour for high-temperature oilfield applications. Geosyst. Eng. 2020, 1-11.

60. Alsaba, M.; Al Marshad, A.; Abbas, A.; Abdulkareem, T.; Al-Shammary, A.; Al-Ajmi, M.; Kebeish, E. Laboratory evaluation to assess the effectiveness of inhibitive nano-water-based drilling fluids for Zubair shale formation. J. Pet. Explor. Prod. Technol. 2020, 10, 419-428.

61. Mady, A.; Mahmoud, O.; Dahab, A.S. Nanoparticle-based drilling fluids as promising solutions to enhance drilling performance in Egyptian oil and gas fields. Int. J. Ind. Sustain. Dev. 2020, 1, 24-38.

62. Sadeghalvaad, M.; Sabbaghi, S. Application of TiO2/polyacrylamide Core-Shell nanocomposite as an additive for controlling rheological and filtration properties of water-based drilling fluid. J. Nanofluids 2017, 6, 205-212. 
63. Nizamani, A.; Ismail, A.R.; Junin, R.; Dayo, A.; Tunio, A.; Ibupoto, Z.; Sidek, M. Synthesis of Titania-Bentonite nanocomposite and its applications in water-based drilling fluids. Chem. Eng. Trans. 2017, 56, 949-954.

64. Aftab, A.; Ismail, A.R.; Ibupoto, Z.; Akeiber, H.; Malghani, M. Nanoparticles based drilling muds a solution to drill elevated temperature wells: A review. Renew. Sustain. Energy Rev. 2017, 76, 1301-1313.

65. Jha, N.K.; Lebedev, M.; Iglauer, S.; Ali, M.; Roshan, H.; Barifcani, A.; Sangwai, J.S.; Sarmadivaleh, M. Pore scale investigation of low salinity surfactant nanofluid injection into oil saturated sandstone via X-ray micro-tomography. J. Colloid Interface Sci. 2020, 562, 370-380.

66. Al-Anssari, S.; Nwidee, L.; Ali, M.; Sangwai, J.S.; Wang, S.; Barifcani, A.; Iglauer, S. Retention of silica nanoparticles in limestone porous media. In Proceedings of the SPE/IATMI Asia Pacific Oil \& Gas Conference and Exhibition, Jakarta, Indonesia, 17-19 October 2017; Society of Petroleum Engineers: Houston, TX, USA, 2017.

67. Najimi, S.; Nowrouzi, I.; Manshad, A.K.; Farsangi, M.H.; Hezave, A.Z.; Ali, J.A.; Keshavarz, A.; Mohammadi, A.H. Investigating the effect of $[\mathrm{C} 8 \mathrm{Py}][\mathrm{Cl}]$ and $[\mathrm{C} 18 \mathrm{Py}][\mathrm{Cl}]$ ionic liquids on the water/oil interfacial tension by considering Taguchi method. J. Pet. Explor. Prod. Technol. 2019, 9, 2933-2941.

68. Dahraj, N.U.; Ali, M.; Khan, M.N. End of linear flow time picking in long transient hydraulically fractured wells to correctly estimate the permeability, fracture half-length and original gas in place in liquid rich shales. In Proceedings of the PAPG/SPE Pakistan Section Annual Technical Conference and Exhibition, Islamabad, Pakistan, 21-23 November 2016; Society of Petroleum Engineers: Houston, TX, USA, 2016.

69. Jha, N.K.; Ali, M.; Iglauer, S.; Lebedev, M.; Roshan, H.; Barifcani, A.; Sangwai, J.S.; Sarmadivaleh, M. Wettability alteration of quartz surface by low-salinity surfactant nanofluids at high-pressure and high-temperature conditions. Energy Fuels 2019, 33, 7062-7068.

70. Ali, M.; Sahito, M.F.; Jha, N.K.; Memon, S.; Keshavarz, A.; Iglauer, S.; Saeedi, A.; Sarmadivaleh, M. Effect of Nanofluid on CO2wettability reversal of sandstone formation; implications for CO2 geo-storage. J. Colloid Interface Sci. 2019, 559, 304-312.

71. Ali, M.; Al-Anssari, S.; Shakeel, M.; Arif, M.; Dahraj, N.U.; Iglauer, S. Influence of miscible CO2 flooding on wettability and asphaltene precipitation in indiana lime stone. In Proceedings of the SPE/IATMI Asia Pacific Oil \& Gas Conference and Exhibition, Jakarta, Indonesia, 17-19 October 2017; Society of Petroleum Engineers: Houston, TX, USA, 2017. [Google Scholar]

72. Bahraminejad, H.; Khaksar Manshad, A.; Riazi, M.; Ali, J.A.; Sajadi, S.M.; Keshavarz, A. CuO/TiO2/PAM as a Novel Introduced Hybrid Agent for Water-Oil Interfacial Tension and Wettability Optimization in Chemical Enhanced Oil Recovery. Energy Fuels 2019, 33, 10547-10560.

73. Al-Anssari, S.; Arain, Z.-U.-A.; Barifcani, A.; Keshavarz, A.; Ali, M.; Iglauer, S. Influence of pressure and temperature on CO2nanofluid interfacial tension: Implication for enhanced oil recovery and carbon geosequestration. In Proceedings of the Abu Dhabi International Petroleum Exhibition \& Conference, Abu Dhabi, UAE, 12-15 November 2018; Society of Petroleum Engineers: Houston, TX, USA, 2018.

74. Al-Anssari, S.; Barifcani, A.; Keshavarz, A.; Iglauer, S. Impact of nanoparticles on the CO2-brine interfacial tension at high pressure and temperature. J. Colloid Interface Sci. 2018, 532, 136-142.

75. Asl, H.F.; Zargar, G.; Manshad, A.K.; Takassi, M.A.; Ali, J.A.; Keshavarz, A. Effect of SiO2 nanoparticles on the performance of L-Arg and L-Cys surfactants for enhanced oil recovery in carbonate porous media. J. Mol. Liq. 2020, 300, 112290.

76. Al-Anssari, S.; Ali, M.; Memon, S.; Bhatti, M.A.; Lagat, C.; Sarmadivaleh, M. Reversible and irreversible adsorption of bare and hybrid silica nanoparticles onto carbonate surface at reservoir condition. Petroleum 2019, 1-31.]

77. Jha, N.; Ali, M.; Sarmadivaleh, M.; Iglauer, S.; Barifcani, A.; Lebedev, M.; Sangwai, J. Low salinity surfactant nanofluids for enhanced $\mathrm{CO} 2$ storage application at high pressure and temperature. In Proceedings of the Fifth $\mathrm{CO} 2$ Geological Storage Workshop, Utrecht, The Netherlands, 21-23 November 2018; European Association of Geoscientists \& Engineers: Db Houten, The Netherlands, 2018; pp. 1-4.

78. Ali, M. Effect of Organic Surface Concentration on CO2-Wettability of Reservoir Rock; Curtin University: Sarawak, Malaysia, 2018.

79. Ali, M.; Dahraj, N.U.; Haider, S.A. Study of asphaltene precipitation during CO2 injection in light oil reservoirs. In Proceedings of the SPE/PAPG Pakistan Section Annual Technical Conference, Islamabad, Pakistan, 24-25 November 2015; Society of Petroleum Engineers: Houston, TX, USA, 2015.

80. Ali, M.; Al-Anssari, S.; Arif, M.; Barifcani, A.; Sarmadivaleh, M.; Stalker, L.; Lebedev, M.; Iglauer, S. Organic acid concentration thresholds for ageing of carbonate minerals: Implications for CO2 trapping/storage. J. Colloid Interface Sci. 2019, 534, 88-94.

81. Ali, M.; Arif, M.; Sahito, M.F.; Al-Anssari, S.; Keshavarz, A.; Barifcani, A.; Stalker, L.; Sarmadivaleh, M.; Iglauer, S. CO2-wettability of sandstones exposed to traces of organic acids: Implications for CO2 geo-storage. Int. J. Greenh. Gas Control 2019, 83, 61-68.

\section{Keywords}

Unconventional reservoirs; shale inhibition; drilling technology 